\title{
Academic achievement of college students and their locus of control
}

\author{
Ruhanshi Mathur*
}

\begin{abstract}
The main aim of the study was to find out whether the locus of control of the individuals, of college going age, has any effect on their academic performances or not. The objective was to conduct a comparative study of the academic achievement and locus of control of college students. The researcher tried to gather a fair response from the total of 60 subjects between the age group of 18-21. The subjects were chosen randomly within the Pandit Deendayal Petroleum University. This study did not include effect of gender on the responses, as the locus of control is more of a cognitive drive which is independent from the gender specific ideology of the subjects. The research instruments used were Locus of control inventory (which reflects the way in which students feel about what happens in their academic institutions) and Life experience inventory (which reflects the experiences of life). The subjects were made to fill both the questionnaires and then the items were scored and results were analyzed. The scores were given to the subjects' response based on the norms provided. Thereby each questionnaire response was scored and subjects were divided into two groups, namely, High on Internality (I) and Low on Internality (E). Further to this, the subjects were made to supply their overall academic performance grade, which was further analysed for each of the two groups. The two groups showed a clear indication that the group with high internality had a better Mean of their overall performance grade,7.40, whereas the latter showed a weak overall performance grade of 5.93. Also, the two groups showed a well correlation of the type of locus of control as per the locus of control inventory and life experience inventory (0.97), depicting a true locus of control that the subjects follow as per their experiences of life and the way they perceive about their academia in the college. The Mean and Standard deviation of the scores of the two groups were 30,19 and 5,6 respectively. Whereas the Life experience inventory showed a Mean of 17 and 10.
\end{abstract}

Recommendations: Increase the sample size as that proved to be a limitation to this study. Further more tests could prove a better result for a larger sample size.

A study across ages and socio-economic group is also possible and might give different results.

KEY WORDS: Internality, Locus, Correlation, Cognitive, Academia

*Student, Pandit Deendayal Petroleum University, Ahmedabad, Gujarat 


\section{INTRODUCTION}

In personality psychology, locus of control refers to the extent to which individuals believe that they can control events that affect them. Understanding of the concept was developed by Julian B. Rotter in 1954, and has since become an aspect of personality studies. A person's "locus" (Latin for "place" or "location") is conceptualised as either internal (the person believes they can control their life) or external (meaning they believe that their decisions and life are controlled by environmental factors which they cannot influence).

Individuals with a high internal locus of control believe that events in their life derive primarily from their own actions; for example, when receiving test results, people with an internal locus of control would praise or blame themselves and their abilities, whereas people with a high external locus of control would praise or blame the teacher or the test.

Locus of control has generated much research in a variety of areas in psychology. The construct is applicable to fields such as educational psychology, health psychology or clinical psychology. There will probably continue to be debate about whether specific or more global measures of locus of control will prove to be more useful. Careful distinctions should also be made between locus of control (a concept linked with expectancies about the future) and attributional style (a concept linked with explanations for past outcomes), or between locus of control and concepts such as self-efficacy. The importance of locus of control as a topic in psychology is likely to remain quite central for many years.

Locus of control has also been included as one of four dimensions of core self-evaluations one's fundamental appraisal of oneself - along with neuroticism, self-efficacy, and selfesteem. In a follow-up study, Judge et al. (2002) argued the concepts of locus of control, neuroticism, self-efficacy and self-esteem measured the same, single factor. The concept of core self-evaluations was first examined by Judge, Locke, and Durham (1997), and since has proven to have the ability to predict several work outcomes, specifically, job satisfaction and job performance.

Various studies have been conducted across the globe to understand and establish a correlation between academic achievement and locus of control. The results of majority of the studies show that academic achievement is significantly affected by the locus of control of individuals. . The aim of this study is to reconfirm and re-establish the correlations between the variables.Locus of control is the personal belief about the extent to which one's behaviors influence a specific outcome (Rotter, 1966). ${ }^{[1]}$

Rotter (1975) cautioned that internality and externality represent two ends of a continuum, not an either/or typology. Internals tend to attribute outcomes of events to their own control. People who have internal locus of control believe that the outcomes of their actions are results of their own abilities. Internals believe that their hard work would lead them to obtain positive outcomes. They also believe that every action has its consequence, which makes them accept the fact that things happen and it depends on them if they want to have control over it or not. Externals attribute outcomes of events to external circumstances. People that have external locus of control believe that many things that happen in their lives are out of their control. They believe that their own actions are a result of external factors that are beyond their control. Rotter in his study suggested that people that have external locus of control have four types of beliefs which include the following: powerful others such as doctors, 
nurses, fate, luck and a belief that the world is too complex to predict its outcomes. People that have external locus of control tend to blame others for the outcomes rather than themselves.

Rotter described internals as individuals who believe that success or failure is due to their own efforts, while externals are those who believe that the reinforcers in life are controlled by luck, chance, or powerful others. Externals see little impact of their own efforts on the amount of reinforcement they receive. Numerous studies about factors associated with academic performance have identified contextual and social characteristics of students as important factors. These factors include family, peers, school, and community. ${ }^{[2]}$ Julian Rotter is credited for introducing the concept of Locus of Control. His work was largely based off the work of Albert Bandura, who developed the social learning theory. Rotter explains that humans can interpret events as being either a result of one's own actions or external factors. He goes on to suggest that whether or not people believe a situation or event is under their own control will influence their reward expectancy and behaviour. ${ }^{[5]}$

Previous studies have also documented two psychosocial factors, locus of control and selfefficacy, as important predictors of academic performance of college students. Students who believe they are responsible for their own behavior are described as having an internal locus of control. Those who believe that other factors such as luck, fate, chance, or powerful others determine their life outcomes, rather than their own behavior are described as having an external locus of control. ${ }^{[3]}$

Jones and colleagues (1995) also found a relationship between Locus of Control and study skills. A study by Onwuegbuzie and Daley (1998) showed that those with very good study skills tended to have an internal academic Locus of Control. Richardson (1995) found, in a sample of Caribbean students, that internality was more prominent in older students compared to younger students. Janssen and Carton (1999) showed that internal students in their samples began work on tasksmore promptly than externals, and turned assignments in sooner. Skinner (2003) suggests that the Academic Locus of Control scale can be an important tool forcounselors working with college-bound students with learning disabilities, as it can be used tomonitor Locus of Control and perhaps assist in a shift toward internality.

\section{METHODOLOGY}

For the purpose of this study the target audience selected was between the age group of 1821. A sample of 60 college students was randomly chosen from Pandit Deendayal Petroleum University, Ahmedabad city, engineering and arts stream mixed. The researcher used two questionnaires namely locus of control (loco) inventory and Life experience inventory. Each subject was required to fill both these questionnaires one after the other. The first questionnaire is locus of control inventory. The locus of control orientations are reflected in the way people feel about what happens in their academic institutions, how much of the control they show fromjust a mere Chance/Luck (EC), or from other factors that includes environment, parents, other people, friends etc (EO). It measures 3 dimensions - 
$\mathrm{I}$ (internality),E(others) and $\mathrm{E}$ (chance). This questionnaire consisted of 30 questions and a 5 point scale was used in scoring responses. The subject was required to read the question and choose the most appropriate option. The responses were thereby scored as per the norm provided and the subjects were grouped initially in the three groups as per their scores in I, EO and EC. Thereafter the Mean and standard deviation of the I and E scores was found. And the ranges were fixed as per Mean $\pm 1 / 2$ Std.dev. Firstly the subjects with I $>E$ were grouped as Internal and External respectively. Thereafter on the basis of the ranges, they were regrouped as having Internal Locus or External Locus. The other questionnaire - life experience inventory, was based on the experiences of people in their lives. It consisted of 25 pairs of proverbs with 2 response sets of each. The subject was required to encircle the most appropriate answer. The responses were scored as per the norm given and their mean and standard deviation was found. The Mean was 16, and thus people with scores above 15 were grouped as High on Internality and the ones less than 13 as Low on Internality. There was no time limit for both the questionnaires. After the grouping was done, the correlation found between the subjects between their two questionnaires to establish their validity of responses. Then the overall academic performance index of each subject was mapped against them, and the Mean scores of both the groups were found to establish the comparison between the performance of the two groups.

\section{RESULTS AND DISCUSSIONS}

\begin{tabular}{|c|c|c|}
\hline Sl. No. & Group & Mean of Academic Grade \\
\hline 1. & Internal Locus Group & 7.40 \\
\hline 2. & External Locus Group & 5.93 \\
\hline
\end{tabular}

Table 1. Comparision of Performance and Locus of Control

\begin{tabular}{|c|c|c|c|}
\hline & I & EO & EC \\
\hline Mean & 30 & 19 & 16 \\
\hline Std. Dev & 4 & 5 & 7 \\
\hline Upper Range (Mean+(1/2)Std) & 33 & 22 & 20 \\
\hline Lower Range (Mean-(1/2)Std) & 28 & 17 & 13 \\
\hline
\end{tabular}

Table 2. Mean, standard deviation and ranges for I, EO and EC scores

\begin{tabular}{|c|c|}
\hline $\begin{array}{c}\text { Correlation Coefficient ( } \\
\text { E ) }\end{array}$ & 0.97563 \\
\hline $\begin{array}{c}\text { Correlation Coefficient ( } \\
\text { I ) }\end{array}$ & 0.97997 \\
\hline
\end{tabular}

Table 3. Correlation between the External and Internal Subjects of Loco and Life Experience

The table 1. Shows the strong relation between the internal locus group people with a higher average academic grade. The table 2 . Shows the mean, and standard deviation of the scores of I, EO and EC, these values were used to form the upper range and lower range as per the norms to classify the subjects as per their locus of control. Then a strong correlation coefficient in table 3 shows the validity of the responses of the subjects as per both the 
questionnaires. Because of high correlation, we found that the subjects with high internality in the life experience inventory were also the internal locus subjects in the loco inventory questionnaire.

\section{CONCLUSIONS}

As it is evident from the analysis from table 1. that the average overall academic performance score for the subjects with an Internal locus of control/high on internality is more than that of those with an External locus of Control/low on internality. It can thus be concluded on the basis of the above research made that, college going students with an internal locus of control can be expected to perform better in their academics and also have a positive attitude towards life. Whereas the ones with an external locus of control are expected not to perform as well as the previous case.

However, having concluded to this doesn't totally prove the High Internality people to always be the achievers or the low internality people to be less successful. The study limits to a small number of subjects. Also, the subjects with a diversified socio-economic conditions could display a slightly changed results.

Still, as mostly seen, even this research points towards a good relation between the academic performance and Internal Locus of control.

\section{RECOMMENDATIONS AND LIMITATIONS}

There were various limitations found to this study. Firstly, Its age specific since its targeting only a particular age group ,i.e., college students (18-25), so it limits from getting a broader view of the subject. Also there will be an unbiased ratio between the genders while conducting the study.

Another problem is the Genuineness of the responses ,i.e., whether the person is responding and filling the questionnaire in an uninterested manner or not, affects the end result. The sample size taken for this study was 60 . This probably could have been a limitation for our study since the sample size was too small to represent the population

\section{REFERENCES:}

1. [1]College Student Journal Publisher: Project Innovation (Alabama) Audience: Academic Format: Magazine/Journal Subject: Education Copyright: COPYRIGHT 2007 Project Innovation (Alabama) ISSN: 0146-3934

2. [2]Murphy, 1986; Bisnaire et al., 1990; Caldas \& Bankston, 1997; Halle et al., 1997; Israel \& Hartless, 2001; Shumow \& Miller; 2001; Henderson \& Mapp, 2002; Furrer $\&$ Skinner, 2003; and Pratts, 2004). ProQuest Dissertations and Theses, 2009

3. [3],[4]Renea Yates,ProQuest Dissertations and Theses, 2009, Dissertation 
4. [5] Hoffmann, M. \& Schenk, J. (1985). The logic of operationalization of the locusof-control concept of Rotter: Examination of the bipolarity of internal external control. Diagnostica, 31, 93-104

5. Carlson, N.R., et al. (2007). Psychology: The Science of Behaviour - 4th Canadian ed.. Toronto, ON: Pearson Education Canada.

6. Dormann, C.; Fay, D.; Zapf, D.; Frese, M. (2006). "A state-trait analysis of job satisfaction: On the effect of core self-evaluations". Applied Psychology: an International Review 55 (1): 27-51.doi:10.1111/j.1464-0597.2006.00227.x.

7. Furnham \& Steele (1993). Measuring Locus of Control: A critique of general, children's, health- and work-related Locus of Control questionnaires. British Journal of Psychology, 84, 443-479

8. Hashway, R. M. (1990). Academic Locus of Control and the collegiate experience. Research \& Teaching in Developmental Education, 7, 45-54.

9. Ibrahim, A. M. (1996). A cross-cultural validation of Trice's academic Locus of Control scale for college students in an Omani sample. Perceptual and Motor Skills, 83, 823-829.

10. Iskender, M. \& Akin, A. (2010). Social self-efficacy, academic Locus of Control, and internet addiction. Computers and Education, 54, 1101-1106

11. Janssen, T. \& Carton, J. S. (1999). The effects of Locus of Control and task difficulty on procrastination. Journal of Genetic Psychology, 160, 436-442.

12. Jones, C. H., Slate, J. R. \& Marini, I. (1995). Locus of Control, social interdependence academic preparation, age, study time, and the study skills of college students. Research in the Schools, 2, 5-62.

13. Judge, T. A.; Locke, E. A.; Durham, C. C. (1997). "The dispositional causes of job satisfaction: A core evaluations approach". Research in Organizational Behavior 19: 151-188.

14. Judge, Timothy A.; Erez, Amir; Bono, Joyce E.; Thoresen, Carl J. (1 January 2002). "Are measures of self-esteem, neuroticism, locus of control, and generalized self-efficacy indicators of a common core construct?". Journal of Personality and Social Psychology 83 (3): 693-710.doi:10.1037/0022-3514.83.3.693. PMID 12219863.

15. Ogden, E. P. \& Trice, A. D. (1986). The predictive validity of the Academic Locus of Control Scale for college students: Freshman outcomes. Journal of Social Behavior and Personality, 1, 649-652.

16. Training Instruments For Hrd And Od (Book + Cd), 2/E, Pareek, 162-165.

17. Onwuegbuzie, A. J. \& Daley, C. E. (1998). Study skills of undergraduates as a function of academicLocus of Control, self-perception, and social interdependence. Psychological Reports, 83, 595-598.

18. Richardson, A. G. (1995). Academic Locus of Control of university students: A Caribbean case study. Perceptual and Motor Skills, 81, 1388-1390.

19. Skinner, A. L. (2003). Using Locus of Control to improve self-determination and outcomes for consumers with learning disabilities. Journal of Applied Rehabilitation Counseling, 34, 27-32.

20. Trice, A. (1985). An academic Locus of Control scale for college students. Perceptual and Motor Skills, 61, 1043-1046

21. Trice, A. et al. (1987). Concurrent validity of the Academic Locus of Control Scale. Educational and Psychological Measurement, 47, 483-486 